\title{
Deposition of aluminium in tissues of rabbits exposed to inhalation of low concentrations of $\mathrm{Al}_{2} \mathrm{O}_{3}$ dust
}

\author{
H B Röllin, P Theodorou, T A Kilroe-Smith
}

\begin{abstract}
With strong evidence coming to light for the toxicity of aluminium (Al), especially to the brain, investigation into the effects of inhalation of low concentrations of $\mathrm{Al}$ dust in animal models has become important. This study follows up previous observations on the effects of $\mathrm{Al}$ on the concentrations of essential metals in serum of workers exposed to inhalation of low concentrations of $\mathrm{Al}$ dust, with a study of the concentrations of $\mathrm{Al}$ in tissues of rabbits exposed to $\mathrm{Al}$ dust at one twentieth of the threshold limit value (TLV). Even at this low concentration, the amount of $\mathrm{Al}$ in the brains of these animals was nearly two and a half times as high as that of the control animals. The concentrations in other tissues were similar to normal. At the same time, the concentrations of $\mathrm{Al}$ in the serum was only slightly raised, indicating that this variable is a poor marker for the effects of $\mathrm{Al}$ on the body. It is suggested that an extensive study is needed to determine a more correct TLV and health based permissible concentration for occupational exposure to Al.
\end{abstract}

New evidence of a link between $\mathrm{Al}$ and neurotoxic effects in occupationally exposed subjects emerged at the second international conference on Alzheimer's disease and related disorders, held in July 1990 in Toronto, Canada. Sandra Rifat of the University of Toronto studied a group of retired Canadian mine workers who had been exposed during their working life to inhalation of a finely ground $\mathrm{Al}$ powder, thought to be a prophylactic measure against silicosis. She found that those miners had suffered a degree of mental impairment. ${ }^{1}$ She also found a clear

Department of Biochemistry, National Centre for Occupational Health, PO Box 4788, Johannesburg, 2000, South Africa

H B Röllin, P Theodorou, T A Kilroe-Smith dose-response effect. Although $\mathrm{Al}$ can be absorbed through the respiratory organs, little research has been done on its toxic effects in workers exposed in industry, although such exposure is common. Hošovski et al studied the mental abilities of workers exposed to high concentrations of $\mathrm{Al}$ dust in an $\mathrm{Al}$ foundry and found changes in their psychomotor and intellectual abilities. ${ }^{2}$ In a previous study of foundry workers we established that very small changes in serum Al concentrations (although statistically significant) are accompanied by conclusive changes in the concentrations of two essential metals-namely, copper and zinc. ${ }^{3}$ The most interesting observation was that these changes were seen at an atmospheric Al dust concentration well below $1 \mathrm{mg} / \mathrm{m}^{3}$ as measured at those foundries. We concluded that the effect on the essential metals was possibly due to the displacement of these metals from the tissues by $\mathrm{Al}$. To study this further, we needed to establish if a deposition of $\mathrm{Al}$ in body organs occurred as a result of exposure to low concentrations of $\mathrm{Al}$ dust similar to the concentration that is present in these foundries. We therefore designed an experiment that enabled us to monitor changes in the concentrations of $\mathrm{Al}$ in the serum of rabbits exposed to low concentrations of $\mathrm{Al}$ dust $\left(0.56(\mathrm{SD} 0.17) \mathrm{mg} \mathrm{Al} / \mathrm{m}^{3}\right)$ over a period of five months. After completion of the dust exposure period selected tissues were removed and analysed for $\mathrm{Al}$ content. We chose rabbits because it was found by Yokel ${ }^{4}$ that aluminium has the ability to produce behavioural defects in rabbits and persistently raised tissue concentrations of $\mathrm{Al}$ that mimic the pattern in man.

Materials and Methods

Sixteen young adult female specific pathogen free New Zealand white rabbits were used. The animals were divided without conscious bias into groups of eight controls and eight exposed. Each was housed in a separate cage for the duration of the experiment and given a standard laboratory diet and tap water. The group of eight exposed rabbits was dusted in the dusting chamber with $\mathrm{Al}_{2} \mathrm{O}_{3}$ at a concentration of 
$0.56\left(\mathrm{SD} \mathrm{0.17)} \mathrm{mg} \mathrm{Al} / \mathrm{m}^{3}\right.$ for five months, eight hours a day, five days a week. Care was taken to dispose of food leftovers at the end of each dusting day, and food containers were rinsed. New food was then supplied to prevent accumulation of $\mathrm{Al}$ in the food. Every two weeks $2 \mathrm{ml}$ of blood were withdrawn from an ear vein of each rabbit. Precautions were taken to avoid contamination during collection. Becton-Dickinson syringes were used to sample the blood, which was then transferred into Sterilin tubes (Sterilab Services catalog No $144 \mathrm{AS}$ ). These were shown to be $\mathrm{Al}$ free. After clotting, the blood samples were centrifuged at $3000 \mathrm{rpm}$. The resulting serum was transferred into other Sterilin tubes and immediately frozen and stored at $-20^{\circ} \mathrm{C}$ until analysed.

On the day of completion of the experiment, the animals were killed with pentobarbital sodium at a dose of $200 \mathrm{mg} / \mathrm{kg}$ body weight and exhaustively perfused through the left ventricle with $0.9 \%$ aqueous $\mathrm{NaCl}$. The $\mathrm{NaCl}$ solution had been previously tested and found to be $\mathrm{Al}$ free. The brain, lung, liver, heart, kidney, and sternum were removed. They were rinsed with purified water, blotted on a clean tissue, and dried in an oven at $80^{\circ} \mathrm{C}$ for 24 hours. The dry tissues were powdered in an agate mortar, defatted with chloroform methanol mixture (2:1), and dried again at $80^{\circ} \mathrm{C}$ for 12 hours. The dried defatted tissues were again powdered and stored in Sterilin tubes at $-20^{\circ} \mathrm{C}$ until analysed. Serum and representative tissue samples were analysed for content of Al using a Varian Model AA975 atomic absorption spectrophotometer equipped with a GTA-95 furnace and autosampler as previously described. ${ }^{5}$ All samples were analysed using the method of addition to avoid matrix interferences. Tissues were dry ashed in platinum crucibles to eliminate contamination. To test the method for serum a certified standard of $\mathrm{Al}$ in serum was also measured (Seronorm trace elements from Nycomed AS, Norway). A study of the recovery of Al from various tissues has been reported previously. ${ }^{5}$ The statistical significance of differences in Al concentration between exposed and control groups with respect to serum and the tissues was determined by Student's $t$ test.

\section{Results}

The figure shows the change in $\mathrm{Al}$ concentrations in serum with time of exposure. It may be represented by the equation: Al concentration $=0.00906 \times$ days of exposure $+2 \cdot 15$ with a regression coefficient of $r=0.47$.

A cyclic change in the concentration of $\mathrm{Al}$ apparently occurs with an average period of about 53 days, but with a steady slow rise in the serum concentration.

The table shows the mean $\mathrm{Al}$ concentrations in different tissues on completion of exposure to dust as compared with the controls. Each tissue, whether for the standard graph or for the individual Al determinations, was weighed in duplicate ( $\pm 20 \mathrm{mg}$ dry tissue) and each of the duplicate samples was analysed in triplicate.

The lung has the highest concentration of $\mathrm{Al}$. This is to be expected if clearance from the lung is slower than the deposition by inhalation, resulting in accumulation.

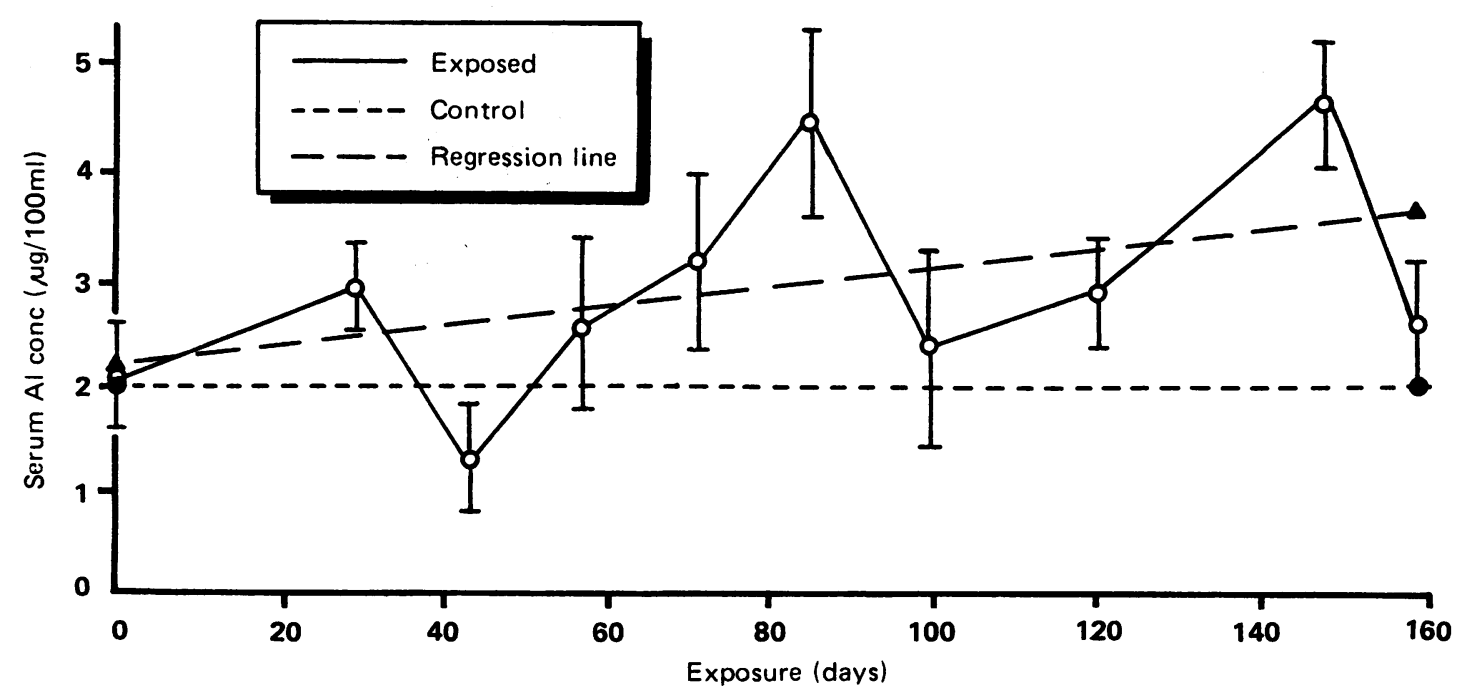

Figure Changes in serum Al concentrations in rabbits with time of exposure. 
Table Comparison of Al concentrations in controls and dusted rabbits

\begin{tabular}{|c|c|c|c|c|}
\hline Tissue & $\begin{array}{l}\text { Controls } \\
(n=8) \\
\text { Al conc }\end{array}$ & $\begin{array}{l}\text { Exposed } \\
(n=8) \\
A l \text { conc }\end{array}$ & $\begin{array}{l}\% \text { Of } \\
\text { control }\end{array}$ & p Valuét \\
\hline $\begin{array}{l}\text { Brain } \\
\text { Lung } \\
\text { Liver } \\
\text { Kidney } \\
\text { Heart } \\
\text { Bone }\end{array}$ & $\begin{array}{l}4.1(2.9) \\
1.7(1.3) \\
\mathrm{ND} \\
3.0(2.0) \\
10.7(2.2) \\
18.2(5.0)\end{array}$ & $\begin{array}{r}10 \cdot 1(4 \cdot 1) \\
270(149) \\
1 \cdot 2(1 \cdot 0) \\
4 \cdot 9(3 \cdot 7) \\
7 \cdot 5(2 \cdot 7) \\
22 \cdot 2(4 \cdot 1)\end{array}$ & $\begin{array}{r}247 \\
15800 \\
165 \\
70 \\
122\end{array}$ & $\begin{array}{l}<0.005 \\
<0.001 \\
\overline{N S} \\
<0.005 \\
<0.02\end{array}$ \\
\hline
\end{tabular}

*Mean $\mu \mathrm{g} \mathrm{Al} / \mathrm{g}$ dry tissue (SD).

$t \mathrm{p}=$ Probability for a two tailed Student's $t$ test.

ND $=$ Not detectable.

The sternum showed a minor increase in concentration $(22 \%)$, whereas the brain showed a highly significant increase $(147 \%)$. Heart muscle showed a $30 \%$ decrease.

\section{Discussion}

The appreciable accumulation of $\mathrm{Al}$ in the body tissues of rabbits exposed to very low concentrations of $\mathrm{Al}_{2} \mathrm{O}_{3}$ dust $\left(0.56(\mathrm{SD} 0.17) \mathrm{mg} \mathrm{Al} / \mathrm{m}^{3}\right)$ over a period of only five months is surprising. That serum $\mathrm{Al}$ concentrations only increased slightly confirms the limited binding capacity of plasma for $\mathrm{Al}$ as reported by Kavalchik et al, ${ }^{6}$ and suggests that concentrations of $\mathrm{Al}$ in serum are not a good reflection of body burden. Excess of $\mathrm{Al}$ appears to be translocated to other tissue stores. Our results show that rabbit organs have the ability to store Al. The high concentration of $\mathrm{Al}$ in lung tissue confirms the very slow rate of uptake of $\mathrm{Al}_{2} \mathrm{O}_{3}$ in vivo. Nevertheless, we found a big increase in the $\mathrm{Al}$ concentrations in the brain $(2 \mathrm{p}<0.005)$, which is particularly disturbing in the light of the neurotoxic effects of this element. Also, one cannot overlook the fact that the Al concentrations in the serum of exposed animals were lower than those presumably associated with encephalopathy in patients receiving dialysis. ${ }^{7}$ Moreover, the cyclic variation in serum Al concentration appears to disqualify it as a reliable marker for body burden of $\mathrm{Al}$. A reliable marker for body burden of $\mathrm{Al}$ must still be found.

We suggest that extensive studies need to be carried out on the effect of inhalation of $\mathrm{Al}$ in industrial workers in an attempt to reach a correct estimate of the proper TLV and health based permissible concentration for occupational exposure; this appears to need a downward revision in view of our findings on exposures to concentrations one twentieth of the present TLV.8

We thank Mr F Coetzee of the Occupational Hygiene Department for his help and advice with the dusting of the animals and Mrs Mary Colly of the Laboratory Animal Section for her help with the sampling of blood.

Requests for reprints to: H B Röllin, Department of Biochemistry, National Centre for Occupational Health, PO Box 4788, Johannesburg 2000, South Africa.

1 Rifat SL, Eastwood MR, Crapper McLachlan DR, Corey PN. Effect of exposure of miners to aluminium powder. Lancet 1990;336:1162-5.

2 Hošovski Z, Mastelica D, Sunderić D, Radulović D. Mental abilities of workers exposed to aluminium. Med Lav 1990;81:119-23.

3 Röllin HB, Theodorou P, Kilroe-Smith TA. The effect of exposure to aluminium on concentrations of essential metals in serum of foundry workers. $\mathrm{Br} J$ Ind Med 1990;48:243-6.

4 Yokel RA. Persistent aluminium accumulation after prolonged systemic aluminium exposure. Biological Trace Element Research 1983;5:467-74.

5 Röllin HB, Theodorou P, Kilroe-Smith TA. Determination of aluminium in small samples of serum and biopsy samples of bone and soft tissues. Microchemical Journal 1987;35:373-8.

6 Kavalchik MT, Kaehny WD, Hegg AP, Jackson JT, Alfrey AC Aluminium kinetics during hemodialysis. J Lab Clin Med 1978;92:712-20.

7 Elliot HL, Dryburgh F, Fell GS, Sabet S, Macdougall AI. Aluminium toxicity during regular haemodialysis. $B M J$ 1978;1:1101-3.

8 American Conference of Governmental Industrial Hygienists. $T L V$ 's-Threshold limit values for chemical substances in the work environment for 1989-1990. Cincinnati, Ohio: ACGIH, 1989-1990.

Accepted 17 December 1990 